\title{
DINESH BHUGRA
}

\section{Teaching psychiatry through cinema}

Films portray mental illness and mental health problems in a variety of ways. Some can be used to teach medical students and psychiatric trainees about certain aspects of psychiatry: watching a film is useful when learning about mental state examination, how to reach a diagnosis, doctor-patient interactions and personality disorder. I have chosen a list of films to watch for each of these topics; this list is not comprehensive, however, and I encourage readers to identify other films they might wish to use when teaching

\section{Background}

Over the past century, cinema has played a part in the social, political and cultural psyche of our world. We should not underestimate films as a source of entertainment and education and as a significant influence on people's attitudes to mental illness (Gabbard \& Gabbard, 1999). There are important differences between the mainstream Hollywood-based cinema and independent films made in the USA, Europe and other countries. Hollywood cinema is more commercial, and therefore likely to cater for the common denominator.

Films can offer realistic depictions of character styles and psychopathologic disorders, as well as personal and family dynamics, with subtexts alluding to the prevailing social norms. An advantage of using films for teaching is that they are well produced, interesting and lively, and there are no concerns over confidentiality. Characters experience their symptoms in the context of their lives, not in an isolated clinical encounter.

A disadvantage of using films can be the distortion and stigmatising portrayal of mental illness (Levine, 2000). Films can be used in teaching different subjects, including psychology (Fleming et al, 1990), developmental psychopathology (Nissim-Sabat, 1979), and individual and couple therapy (Hesley \& Hesley, 2001).

\section{Suggested films}

I offer my personal choice of films for teaching on the following topics (Box 1). The list is not comprehensive, and readers may have their own preferences.

\section{Mental state examination}

I recommend Harvey, Interesting People, As Good As It Gets, Frances and The Glass Menagerie; Levine (2000) recommends Lone Star and She's So Lovely. I suggest showing clips 5-10 min long, and then encouraging the trainees to discuss a character's appearance, behaviour, abnormal experiences and perceptions, which they can consider in the context of the other characters in the film.

\author{
Mental state examination \\ As Good as It Gets \\ Frances \\ Harvey \\ Interesting People \\ Lone Star \\ Lost Weekend \\ She's So Lovely \\ The Glass Menagerie \\ The Madness of King George \\ The Snake Pit \\ Twelve Monkeys

\section{Diagnosis} \\ Betty Blue \\ Harvey \\ Jerry Maguire \\ Lone Star \\ The Naked Lunch \\ Trainspotting

\section{Doctor-patient interactions \\ Frances \\ M.A.S.H. \\ One Flew Over the Cuckoo's Nest \\ Ordinary People \\ Still of the Night}

\section{Personality disorder} \\ Bullets over Broadway \\ Fatal Attraction \\ Jezebel \\ King of Comedy \\ Play Misty For Me \\ Single White Female \\ Strangers On aTrain \\ Swimming with Sharks \\ Taxi Driver \\ The Caine Mutiny \\ TheTalented Mr Ripley \\ Zelig
}

Box 1. Examples of films suitable for teaching

The trainees can produce formulations, which will introduce them to differential diagnoses, and they can draw up management plans, taking into account any further information they would like to obtain from the protagonist and other characters.

\section{Diagnosis}

One of the difficulties of using films to illustrate psychopathology is that the diagnoses are not always clear. This makes it important to consider differential diagnoses, not ICD-10 (World Health Organization, 1992) or DSM-IV (American Psychiatric Association, 1994) categories. 
(8)

special articles
However, the features of substance misuse may be clearer in a film than in a patient interview (for example, in The Naked Lunch and Trainspotting), and it may be easier to identify different personality disorders or more subtle psychological impairment thanks to the longitudinal perspective of some films (Levine, 2000).

\section{Doctor-patient interactions}

Trainees can learn about the doctor-patient relationship, transference and countertransference, therapeutic boundaries and professionalism. British medical 'soaps' such as Peak Practice and Casualty have examples of insensitive and controlling doctors. Levine (2000) suggests asking the trainees to look at reasons why a doctor behaves in an arrogant manner, so introducing them to the notion that insensitivity to the patient is created by the doctor's defence mechanism. An overly involved therapist, as seen in Ordinary People, can stimulate discussion about the boundaries of therapeutic relationships, while M.A.S.H. offers a superb setting for looking at how doctors deal with working under stress.

\section{Personality disorder}

Two protagonists of antisocial characters - both from Patricia Highsmith novels - stand out. Robert Walker as Bruno Anthony in Hitchcock's Strangers on a Train is a classic example: charming, suave yet irritable, ready to respond angrily, bullying, guiltless and cold-blooded, Walker plays the character perfectly. The second is played by Matt Damon in The Talented Mr Ripley. Other examples of personality disorders include Robert de Niro in Taxi Driver (schizotypal personality), Humphrey Bogart in The Caine Mutiny (paranoid personality) and Bette Davis in Jezebel (narcissistic personality); Fatal Attraction, Single White Female and Play Misty For Me all have characters with borderline personality disorders.

\section{Conclusion}

In this paper, I have given my personal choice of films to use in teaching different aspects of psychiatry. The lists are not comprehensive and I encourage readers to identify their own favourites.

\section{References}

AMERICAN PSYCHIATRIC ASSOCIATION (1994) Diagnostic and Statistical Manual of Mental Disorders (4th edn) (DSM-IV). Washington, DC: APA. enhance the teaching of psychiatry and behavioural sciences. Newsletter of the Association of Directors of Medical Students Education (See www.admesp.org)

FLEMMING, M., PIEDMONT, R. \& HIAM, C. M. (1990) Images of madness: NISSIM-SABAT, D. E. (1979) The teaching of abnormal psychology Teaching of Psychology, 17, 185-187. GABBARD, G. O. \& GABBARD, K. (1999) Psychiatry and the Cinema. Washington, DC: APA Press. through the cinema. Teaching Psychology, 6, 121-123.

WORLDHEALTH ORGANIZATION (1992) TheTenth Revision of the International HESLEY, J.W. \& HESLEY, J. G. (2001) RentTwo Films and Let'sTalk in the Morning. New York: JohnWiley. Classification of Diseases and Related Health Problems (ICD-10). Geneva: WHO.

Dinesh Bhugra Professor of Mental Health and Cultural Diversity, Institute of Psychiatry, De Crespigny Park, London SE5 8AF 